\title{
The Effect of Regionalism and Infrastructure on Bilateral Trade: An Augmented Gravity Analysis for ASEAN
}

\author{
Putu Mahardika Adi Saputra ${ }^{1}$ \\ ${ }^{1}$ Department of Economics, Faculty of Economics and Business, University of Brawijaya, Malang, Indonesia \\ Correspondence: Putu Mahardika Adi Saputra, Department of Economics, Faculty of Economics and Business, \\ University of Brawijaya, Malang, Indonesia. E-mail: putu@ub.ac.id
}

Received: October 9, 2013

Accepted: December 25, 2013

Online Published: February 25, 2014

doi:10.5539/ijef.v6n3p88

URL: http://dx.doi.org/10.5539/ijef.v6n3p88

\begin{abstract}
This paper estimates the effects of regionalism in South East Asia (AFTA), infrastructure, economic size, distance, and common border on the ASEAN trade flows. The trade flow evolutions of 97 ASEAN's partner during 1990-2000 are considered in the analysis through the utilization of cross-sectional and panel gravity model. The results show that as a symbol of regionalism in ASEAN, the coefficient of AFTA and infrastructure are positively significant in affecting the ASEAN trade flows for most periods. The other determinants, i.e. economic size (income), and distance affect significantly the ASEAN trade flows. However, common border is found to have no effect on ASEAN trade.
\end{abstract}

Keyword: international trade, ASEAN, AFTA, gravity analysis

\section{Introduction}

Regionalism has re-emerged as a major concern in the agenda of international system (Behr \& Jokela, 2011). There is no exception for the countries in South East Asian with the AFTA (ASEAN Free Trade Area). Through AFTA, which was initiated in 1992, the ASEAN6 (i.e. Indonesia, Malaysia, the Philippines, Thailand, Singapore and Brunei Darussalam) decided in opening their area for free trade by reducing and eventually abolishing tariff and non-tariff barriers to trade among themselves (see Schiff \& Winters, 1998). However, since it was formed, the establishment of AFTA still raised criticism due to the fact of the relatively low share of intra ASEAN trade in total ASEAN trade (only ranging from $18 \%$ to $22 \%$ ) and the presence of major contribution of non-ASEAN trading partners -Japan, USA and EU- on total value of ASEAN trade (De Melo et al., 1993; Plummer, 1996). In this case, AFTA is viewed in its infancy in terms of its role in boosting trade flows among the members and enhancing region's economic development (OECD, 1995).

Utilizing cross-sectional and panel analysis with the gravity model, this paper attempts to answer the question of what is the effect of regionalism and infrastructure on ASEAN trade during 1990-2000. In addition, we consider also the influence of other dominant factors in the model, such as economic size (income), distance and common border. In this paper, we find that the trade regionalism in ASEAN (AFTA) and infrastructure are positively significant affecting ASEAN trade flows for most periods. Other determinants, i.e. income, and distance show the expected effects, but the common border demonstrates a statistically insignificant impact on ASEAN trade.

The next section of the paper provides a brief overview about ASEAN members' trade and economies. Section 3 will introduces the theoretical review on regional integration. In Section 4, the analytical techniques and methodology are shown and Section 5 describes the empirical results of the model. Finally, Section 6 concludes.

\section{Some Basic Facts about ASEAN Economies}

In general, ASEAN countries depend heavily on exports and inward FDI. Except for Singapore, ASEAN countries commonly rely on natural resources, basic unskilled or semi-skilled industries. Their major employment sectors are agriculture, mining, forestry, and fisheries. As of 2000, manufacturing accounted for more than $20 \%$ of employment in Singapore and Malaysia, 20\% of employment in Vietnam, $14.5 \%$ in Thailand, $13 \%$ in Indonesia and less than $10 \%$ for the rest of ASEAN countries. Other than Singapore, ASEAN countries are not known to have considerable endowment in managerial skills and advanced technology.

The economies of ASEAN are highly trade-dependent. In the period of Asian financial crisis (1997), as shown by Table 1 and Table 2, the ratio of ASEAN export to their GDP was about $46 \%$ while the ratio of their imports to 
GDP was around $49 \%$. After the crisis, ASEAN total GDP declined while exports continued to grow. That resulted in an increase in the exports to GDP ratio to $71 \%$ in 2000 . Conversely, the value of ASEAN imports seemed down, but not as much as the decline of GDP. However, the value of imports bounced back in 2000, bringing the ratio of imports to GDP to $62 \%$. The result was that the ASEAN countries have grown more dependent on trade (particularly on exports) in the post-crisis era. The reason could be due to the emphasis of ASEAN on AFTA deals execution.

Table 1. Total exports of ASEAN to its trading partners, by country of destination, 1993-2000 (Million USD)

\begin{tabular}{lllllllll}
\hline Trade Data & $\mathbf{1 9 9 3}$ & $\mathbf{1 9 9 4}$ & $\mathbf{1 9 9 5}$ & $\mathbf{1 9 9 6}$ & $\mathbf{1 9 9 7}$ & $\mathbf{1 9 9 8}$ & $\mathbf{1 9 9 9}$ & $\mathbf{2 0 0 0}$ \\
\hline Total Exports & 209,626 & 250,820 & 296,697 & 330,617 & 351,570 & 326,002 & 354,293 & 410,986 \\
Total GDP & & & & 723,468 & 694,045 & 473,216 & 546,071 & 577,776 \\
Exports/GDP & & & & 0.4570 & 0.5066 & 0.6889 & 0.6488 & 0.7113 \\
\hline Country of Destination & $\mathbf{1 9 9 3}$ & $\mathbf{1 9 9 4}$ & $\mathbf{1 9 9 5}$ & $\mathbf{1 9 9 6}$ & $\mathbf{1 9 9 7}$ & $\mathbf{1 9 9 8}$ & $\mathbf{1 9 9 9}$ & $\mathbf{2 0 0 0}$ \\
\hline ASEAN & $43,681.1$ & $58,571.5$ & $70,178.9$ & $80,973.7$ & $85,351.8$ & $69,312.9$ & $74,698.9$ & $90,440.8$ \\
Japan & 129 & $34,229.6$ & $42,680.7$ & $43,150.3$ & $42,008.6$ & $34,716.8$ & $37,628.6$ & $51,928.8$ \\
EU-15 & $31,391.5$ & $35,196.4$ & $44,285.9$ & $46,926.0$ & $46,086.7$ & $46,143.6$ & $55,651.3$ & $57,555.0$ \\
USA & $42,008.2$ & $49,370.7$ & $54,993.7$ & $59,515.5$ & $70,034.4$ & $64,620.0$ & $70,003.4$ & $67,685.0$ \\
World Total & 206,637 & 246,765 & 296,697 & 323,361 & 342,670 & 316,651 & 341,067 & 389,758 \\
ASEAN/Total & $21.14 \%$ & $23.74 \%$ & $23.65 \%$ & $25.04 \%$ & $24.91 \%$ & $21.89 \%$ & $21.90 \%$ & $23.20 \%$ \\
Japan/Total & $14.98 \%$ & $13.90 \%$ & $14.39 \%$ & $13.34 \%$ & $12.26 \%$ & $10.96 \%$ & $11.03 \%$ & $13.34 \%$ \\
EU-15/Total & $15.19 \%$ & $14.26 \%$ & $14.93 \%$ & $14.51 \%$ & $13.45 \%$ & $14.57 \%$ & $16.32 \%$ & $14.77 \%$ \\
USA/Total & $20.33 \%$ & $20.01 \%$ & $18.54 \%$ & $18.41 \%$ & $20.44 \%$ & $20.41 \%$ & $20.52 \%$ & $17.37 \%$ \\
\hline
\end{tabular}

Source: ASEAN Trade Statistic Database, 2001.

Table 2. Total imports of ASEAN from its trading partners, by country of origin, 1993-2000 (Million USD)

\begin{tabular}{lllllllll}
\hline Trade Data & $\mathbf{1 9 9 3}$ & $\mathbf{1 9 9 4}$ & $\mathbf{1 9 9 5}$ & $\mathbf{1 9 9 6}$ & $\mathbf{1 9 9 7}$ & $\mathbf{1 9 9 8}$ & $\mathbf{1 9 9 9}$ & $\mathbf{2 0 0 0}$ \\
\hline Total Imports & 226,300 & 271,296 & 325,494 & 357,862 & 364,872 & 268,818 & 294,129 & 360,148 \\
Total GDP & & & & 723,468 & 694,045 & 473,216 & 546,071 & 577,776 \\
Imports/GDP & & & & 0.4946 & 0.5257 & 0.5681 & 0.5386 & 0.6233 \\
\hline Country of Origin & $\mathbf{1 9 9 3}$ & $\mathbf{1 9 9 4}$ & $\mathbf{1 9 9 5}$ & $\mathbf{1 9 9 6}$ & $\mathbf{1 9 9 7}$ & $\mathbf{1 9 9 8}$ & $\mathbf{1 9 9 9}$ & $\mathbf{2 0 0 0}$ \\
\hline ASEAN & $38,763.3$ & $46,911.9$ & $53,602.1$ & $64,211.2$ & $64,621.2$ & $51,604.9$ & $56,781.4$ & $69,150.7$ \\
Japan & $55,702.9$ & $67,302.5$ & $78,535.2$ & $73,310.1$ & $71,264.2$ & $46,693.7$ & $51,244.1$ & $61,404.9$ \\
EU-15 & $31,822.4$ & $38,729.3$ & $46,392.8$ & $57,380.5$ & $51,009.8$ & $33,256.1$ & $34,675.5$ & $36,934.8$ \\
USA & $33,712.7$ & $39,201.7$ & $46,435.1$ & $53,011.4$ & $61,695.0$ & $50,942.2$ & $45,962.0$ & $46,315.3$ \\
World Total & 223,311 & 267,242 & 318,555 & 350,606 & 355,972 & 259,457 & 279,460 & 325,305 \\
ASEAN/Total & $17.36 \%$ & $17.55 \%$ & $16.83 \%$ & $18.31 \%$ & $18.15 \%$ & $19.89 \%$ & $20.32 \%$ & $21.26 \%$ \\
Japan/Total & $24.94 \%$ & $25.18 \%$ & $24.65 \%$ & $20.91 \%$ & $20.02 \%$ & $18.00 \%$ & $18.34 \%$ & $18.88 \%$ \\
EU-15/Total & $14.25 \%$ & $14.49 \%$ & $14.56 \%$ & $16.37 \%$ & $14.33 \%$ & $12.82 \%$ & $12.41 \%$ & $11.35 \%$ \\
USA/Total & $15.10 \%$ & $14.67 \%$ & $14.58 \%$ & $15.12 \%$ & $17.33 \%$ & $19.63 \%$ & $16.45 \%$ & $14.24 \%$ \\
\hline
\end{tabular}

Source: ASEAN Trade Statistic Database, 2001.

The ASEAN trade patterns look consistent before and after the crisis (1996 vs. 2000). Intra-ASEAN exports contributed around $25 \%$ of total exports in 1996, while it dropped slightly to $23 \%$ in 2000 . Nevertheless, intra-ASEAN imports grew from $18 \%$ of total in 1996 to $21 \%$ in 2000. Developed countries were the most dominant export and import partners of ASEAN. Among them, the most significant importer country was the US, 
which accounted for $18 \%$ of the total value in 1996 and $17 \%$ in 2000 . On the other hand, the most prominent exporter countries for ASEAN were Japan, EU, and the US. They accounted for $21 \%, 16 \%$, and $15 \%$ of the total value, respectively. In recent years, trade with the rest of Asia (China) grew.

In the period of nineties, tariffs became the principal instrument of most ASEAN countries trade policy. Table 3 shows the evolution of average MFN tariff rates in five ASEAN countries during 1990-2000. Singapore recorded the lowest level of tariff, while Thailand and Philippines had much higher tariffs within the region. Indonesia and Philippines seemed to be in the same tier, whereas Malaysia did better than those two countries in opening and liberating its market. Thailand is an interesting case since it demonstrated the sharpest decline of tariff level in the region, i.e. averagely from 44 percent in 1991 to 18 percent in 1999. After the implementation of the General Agreement on Tariff and Trade (GATT), the average tariff in the five ASEAN countries had dropped to between 0 percent and 18 percent.

Table 3. The five ASEAN countries' MFN tariff rates (\%) during 1990-2000 (in average)

\begin{tabular}{|c|c|c|c|c|c|}
\hline & Indonesia & Phillipines & Thailand & Singapore & Malaysia \\
\hline 1990 & 22 & & & & \\
\hline 1991 & & & 44 & 0 & \\
\hline 1992 & & 26 & & & \\
\hline 1993 & & & & & 15 \\
\hline 1994 & 20 & & & & \\
\hline 1995 & & & 23 & & \\
\hline 1997 & & & & & 8 \\
\hline 1998 & 10 & & & & \\
\hline 1999 & & 10 & 18 & & \\
\hline 2000 & & & & 0 & \\
\hline
\end{tabular}

Source: Indonesia, Philippines, Thailand, Singapore, and Malaysia Trade Policy Review (WTO, Various Years).

\section{Theoretical Review}

According to The Theory of Economic Integration of Balassa (1961), the stages of regionalism (economic integration) can be distinguished into seven stages. The first stage is preferential trade area (PTA). PTA unifies countries which agree with the imposition of lower tariffs for each good produced in the member countries (see Table 4). PTA will be followed by free trade area (FTA) where it introduces the abolishment of tariffs among member countries. However, partner countries can still impose its own customs tariff with respect to the third countries. Certificate of origin is needed for FTA in order to evade a trade deflection. The third stage is a custom union (CU). $\mathrm{CU}$ is the extension of FTA where a common external tariff is imposed among member countries and the certificate of origin is no longer needed. The fourth stage is called the common market. In the common market, labor and capital of the member countries start to be able to move freely. The fifth stage is an economic union that unify all market regulations, macro economic and monetary policies and income redistribution policies among member countries. The next stage is monetary union where one common currency is created for all members, such as the European Monetary Union with its single currency, Euro, which is introduced in 2002. The last stage is political union where political institutions are also unified.

\section{Methodology}

\subsection{The Empirical Model}

Since its inception in 1940s, the gravity model has been used extensively in social science. In analogy to the Newtonian gravity model, Stewart in 1947 found strong correlation for traffic, migration, and communication between two places, based on the product of the population size and inversely related to their distance squared. This model became popular in the hand of Tinbergen when the model was applied to the field of international trade. Since then, the gravity equation has become a standard analytical tool for predicting the bilateral trade flows with simultaneous development of its theoretical discussion (see e.g. Bergstrand, 1989; Brulhart and Kelly, 1999; Egger, 2002; Greenaway and Milner, 2002; Matyas, 1997; Montenegro and Soloaga, 2006). 
Table 4. Stages of economic integration

\begin{tabular}{lcccccc}
\hline & $\begin{array}{c}\text { Selective } \\
\text { Tariff }\end{array}$ & $\begin{array}{c}\text { No Internal } \\
\text { Tariffs or } \\
\text { Quotas }\end{array}$ & $\begin{array}{c}\text { Common } \\
\text { External } \\
\text { Tariff }\end{array}$ & $\begin{array}{c}\text { Free Flow } \\
\text { of Factors }\end{array}$ & $\begin{array}{c}\text { Harmonized } \\
\text { Economic } \\
\text { Policies }\end{array}$ & $\begin{array}{c}\text { Unification of } \\
\text { Political } \\
\text { Institutions }\end{array}$ \\
\hline Preferential Trade Area (PTA) & $\mathrm{x}$ & & & & & \\
Free Trade Area (FTA) & $\mathrm{x}$ & $\mathrm{x}$ & & & & \\
Custom Union & $\mathrm{x}$ & $\mathrm{x}$ & $\mathrm{x}$ & $\mathrm{x}$ & & \\
Common Market & $\mathrm{x}$ & $\mathrm{x}$ & $\mathrm{x}$ & $\mathrm{x}$ & $\mathrm{x}$ \\
Economic Union & $\mathrm{x}$ & $\mathrm{x}$ & $\mathrm{x}$ & $\mathrm{x}$ & $\mathrm{x}$ & $\mathrm{x}$ \\
Political Union & $\mathrm{x}$ & $\mathrm{x}$ & $\mathrm{x}$ & $\mathrm{x}$ & &
\end{tabular}

The classical gravity model connects the international trade flows and the economic size of a pair country with their distance through following multiplicative forms:

$$
T_{i j}=C Y_{i}^{\theta 1} Y_{j}^{\theta 2} D_{i j}^{\theta 3} e_{i j}
$$

Where $T_{i j}$ is the international trade flows from country i to country $\mathrm{j}, \mathrm{C}$ is the constant term, $\mathrm{Y}_{i}$ is the income level of the origin country (reporting country), $\mathrm{Y}_{j}$ is the income level of the destination country (trading partner), $\mathrm{D}_{\mathrm{ij}}$ is the distance between the two countries, $\mathrm{e}_{\mathrm{ij}}$ is an error term.

In addition to the classical gravity model equation, we estimate an augmented gravity model equation to analyze the influence of FTA (in this case is AFTA) on the selected ASEAN countries' trade flows (Indonesia, Philippines, Thailand, Singapore and Malaysia). Beside that, we also examine the role of other factors that related to the gravity concept (see Eq. 2).

$$
\operatorname{LogMij}=\alpha+\beta_{1} \log \left(Y_{i} Y_{j}\right)+\beta_{2} \sqrt{D_{i j}}+\beta_{3} \log \left(\operatorname{Inf}_{i} \operatorname{Inf}_{j}\right)+\beta_{4} \text { Dborder }+\beta_{5} \text { DAFTA }+e_{i j}
$$

Where Mij denotes the value of bilateral trade between country $i$ and country $j$. Mij is the value of import between reporting country $(i)$ and its trading partner $(j)$. All explanatory variables in the augmented gravity model are defined as follows.

Income $\left(Y_{i} . Y_{j}\right)$ is the multiplied GDP from both countries (using constant prices at 1995 in million US Dollar). The variable is used to measure the economic size or mass of the countries (see eg., Batra, 2004; Rojas et al., 2005). Specifically, a high level of income in the importing country suggests higher imports while a high level of income in the exporting country indicates a high level of production that increases the availability of export products. We expect the coefficients of the variables to be positive.

Distance $\left(D_{i j}\right)$ is the distance between country $i$ and country $j$. It was measured as the real distance in $\mathrm{km}$ (kilometers) between the center of gravity (capital city) of country $i$ and $j$. Distance is defined as one main variable in the gravity concept, since it increases transport costs which impedes trade (Bougheas et al., 1999; Zarzoso \& Lehmann, 2003). In this paper, its coefficient is expected to be negative.

Infrastructure $\left(\operatorname{Inf} f_{i}\right.$ Inf $f_{j}$ ) describes the facilities which are provided by country $i$ and country $j$ for supporting their bilateral trade activities. The augmentation is inspired from study that was conducted by Bougheas et al. (1999). However, instead of using the length of motorway network, we utilize the telecommunication network (normalized by population) as an infrastructure proxy. The effect of this variable is expected to be positive since a higher level of public infrastructure should reduce transport costs which facilitate trade.

The paper includes dummy variables in order to capture the effects of the FTA establishment and the common border on ASEAN trade flows. Those dummy variables can be explained as follows.

Border (Dborder) is a dummy variable which identify a pair of countries that share a border. This dummy clarifies the effective distance among two countries ( $i$ and $j$ ) which may engage in large volumes of border trade (McCallum, 1995; Anderson \& Wincoop, 2003). The dummy variable for Border is unity if countries $i$ and $j$ share a common border and 0 when they do not.

Regional Trading Arrangements (DAFTA): A country often enters into regional trading agreements with the intention of facilitating bilateral trade. The dummy variable is equal to one when both countries in a given pair belongs to the same regional group (in this case is AFTA bloc) and 0 otherwise. The estimated coefficient will describe the effect of AFTA on the bilateral trade flows for selected ASEAN countries during 1990-2000. 
The coefficients for all dummy variables are expected to be positive since neighboring countries tend to trade more and a membership in trade block will incline to facilitate trade. Based on the explanation above, we decide the hypotheses of the paper as follow.

1). $\mathrm{H}_{0}: \beta 1 ; \beta 3 ; \beta 4 ; \beta 5 \leq 0 ; \mathrm{H}_{1}: \beta 1 ; \beta 3 ; \beta 4 ; \beta 5>0$;

2). $\mathrm{H}_{0}: \beta 2 \geq 0 ; \mathrm{H}_{1}: \beta 2<0$.

We utilize cross section and panel model which will be executed with the data of 1990-2000. Some trade observations are zero, probably due to the low level of trade for those countries that were too small to be recorded, or they are actually a small country and have a problem of remoteness for establishing trade. To ascertain whether their trade is zero or just minimal, we propose two different techniques in the execution of cross section and panel estimations using the gravity model, i.e. first, doing omission for zero pairs in the data set, and second, using Tobit techniques in the gravity equation.

Table 5. Variables, definitions and data sources

\begin{tabular}{|c|c|c|}
\hline Variable & Definition & Source \\
\hline$M_{i j}$ & $\begin{array}{l}\text { Import values between reporting and partner countries } \\
\text { (Thousand USD) }\end{array}$ & NBER and UN Comtrade (various years) \\
\hline$Y_{i} \cdot Y_{j}$ & $\begin{array}{l}\text { Explaining the economic size. It is measured by GDP } \\
\text { (Million USD) at constant price (1995) }\end{array}$ & WDI -World Bank (various years) \\
\hline$D_{i j}$ & $\begin{array}{l}\text { Distance between the capital of reporting and partner } \\
\text { countries (in kilometer) }\end{array}$ & $\begin{array}{l}\text { www.haveman.org and } \\
\text { www.indo.com/distance }\end{array}$ \\
\hline $\operatorname{Inf} f_{i} \cdot \operatorname{In} f_{j}$ & $\begin{array}{l}\text { Explaining the infrastructure. It is measured by the main } \\
\text { telephone lines in operation (unit) that normalized by the } \\
\text { population of the country }\end{array}$ & $\begin{array}{l}\text { International Telecommunication Union (ITU) } \\
\text { - Yearbook of Statistics in Telecommunication } \\
\text { Services (various years) }\end{array}$ \\
\hline Dborder & $\begin{array}{l}\text { A dummy variable that takes value } 1 \text { if countries } i \text { and } j \\
\text { share a common border and } 0 \text { otherwise }\end{array}$ & $\begin{array}{l}\text { http://www.eiit.org/Trade.html or } \\
\text { www.haveman.org }\end{array}$ \\
\hline DAFTA & $\begin{array}{l}\text { A dummy variable is equal to one when both countries in } \\
\text { a given pair belong to the same regional group (in this } \\
\text { case is AFTA bloc) and } 0 \text { otherwise. Value } 1 \text { will be } \\
\text { given to Indonesia, Philippines, Thailand, Singapore and } \\
\text { Malaysia; otherwise is } 0\end{array}$ & $\underline{\text { www.aseansec.org }}$ \\
\hline
\end{tabular}

\subsection{Data Definition}

The gravity model will be applied to examine the trade flows of the five ASEAN countries (Indonesia, Philippines, Thailand, Singapore and Malaysia). The model involves 97 ASEAN's trading partner in the world. Table 5 shows all information about variables and data source used by this paper. The data for the dependent variable $\left(M_{i j}\right)$ are defined as total value of reporting country's imports from its trading partners in thousand US dollars. The independent variable $Y i . Y j$ is measured by GDP of reporting and partner countries (evaluated at 1995 prices). Infi.Infj denotes the infrastructure provided by both countries ( $i$ and $j$ ) which are measured by annual main telephone lines in operation per person.

\section{Empirical Results}

This paper estimates the gravity model given by equation (2) which is constructed into 11 temporal cross-section (from 1990 until 2000) estimations and 1 panel estimation (for 1990 to 2000). Based on the descriptive analysis, we transform the variable of $M_{i j}, Y_{i} . Y_{j}$, Inf $f_{i} \cdot \operatorname{Inf} f_{j}$ into the $\log$ value, and $D i j$ into the square root. Regressions are run for both (cross-section and panel model) in two different techniques. First, regression that eliminates the zero pairs from the data set; Second, regression that reformulates the gravity equation using Tobit technique. Each specific results of equation (2) are presented in Table 6 and Table 7. 
Table 6. Regression results with the first technique ${ }^{\text {a) }}$

\begin{tabular}{|c|c|c|c|c|c|c|c|}
\hline & $\log (\mathbf{Y i . Y j})$ & $\sqrt{ } \mathbf{D i j}$ & $\log ($ Infi.Infj) & Dborder & DAFTA & $\mathbf{R}^{2}$ & $\mathbf{n}$ \\
\hline \multicolumn{8}{|c|}{ Cross-Section Analysis } \\
\hline \multirow[t]{2}{*}{1990} & 0.911 & -0.04 & 0.356 & -0.440 & 1.113 & 0.643 & 430 \\
\hline & $(17.63)^{*}$ & $(-8.17)^{*}$ & $(7.91 .)^{*}$ & $(-0.45)$ & $(2.00)^{* *}$ & & \\
\hline \multirow[t]{2}{*}{1991} & 0.877 & -0.036 & 0.373 & -0.369 & 1.127 & 0.638 & 431 \\
\hline & $(17.12)^{*}$ & $(-8.09)^{*}$ & $(8.27)^{*}$ & $(-0.39)$ & $(2.06)^{* *}$ & & \\
\hline \multirow[t]{2}{*}{1992} & 0.863 & -0.041 & 0.371 & -0.287 & 0.824 & 0.679 & 430 \\
\hline & $(18.35)^{*}$ & $(-9.94)^{*}$ & $(8.81)^{*}$ & $(-0.33)$ & $(1.64)$ & & \\
\hline \multirow[t]{2}{*}{1993} & 0.927 & -0.043 & 0.301 & -0.087 & 0.631 & 0.688 & 440 \\
\hline & $(19.73)^{*}$ & $(-10.50)^{*}$ & $(7.02)^{*}$ & $(-0.10)$ & $(1.25)$ & & \\
\hline \multirow[t]{2}{*}{1994} & 0.929 & -0.038 & 0.301 & -0.287 & 0.894 & 0.718 & 441 \\
\hline & $(21.09)^{*}$ & $(-10.09)^{*}$ & $(7.34)^{*}$ & $(-0.35)$ & $(1.91)^{* * *}$ & & \\
\hline \multirow[t]{2}{*}{1995} & 0.927 & -0.037 & 0.266 & -0.628 & 0.934 & 0.738 & 447 \\
\hline & $(22.58)^{*}$ & $(-10.46)^{*}$ & $(6.70)^{*}$ & $(-0.83)$ & $(2.16)^{* *}$ & & \\
\hline \multirow[t]{2}{*}{1996} & 0.979 & -0.040 & 0.279 & -0.769 & 0.899 & 0.717 & 453 \\
\hline & $(21.23)^{*}$ & $(-10.15)^{*}$ & $(6.17)^{*}$ & $(-0.91)$ & $(1.86)^{* * *}$ & & \\
\hline \multirow[t]{2}{*}{1997} & 1.122 & -0.039 & -0.002 & -0.360 & 0.808 & 0.697 & 451 \\
\hline & $(23.14)^{*}$ & $(-9.64)^{*}$ & $(-0.06)$ & $(-0.42)$ & $(1.63)$ & & \\
\hline \multirow[t]{2}{*}{1998} & 0.982 & -0.045 & 0.230 & 0.093 & 0.854 & 0.690 & 443 \\
\hline & $(19.60)^{*}$ & $(-10.88)^{*}$ & $(4.57)^{*}$ & $(0.10)$ & $(1.68)^{* * *}$ & & \\
\hline \multirow[t]{2}{*}{1999} & 0.988 & -0.040 & 0.216 & 0.009 & 1.123 & 0.709 & 458 \\
\hline & $(21.12)^{*}$ & $(-10.14)^{*}$ & $(4.43)^{*}$ & $(0.01)$ & $(2.32)^{* *}$ & & \\
\hline \multirow[t]{2}{*}{2000} & 0.983 & -0.046 & 0.282 & -0.371 & 1.041 & 0.717 & 464 \\
\hline & $(20.35)^{*}$ & $(-11.38)^{*}$ & $(5.47)^{*}$ & $(-0.42)$ & $(2.07)^{* *}$ & & \\
\hline \multicolumn{8}{|c|}{ Panel Analysis } \\
\hline \multirow[t]{2}{*}{ 1990-2000 } & 0.958 & -0.041 & 0.239 & -0.372 & 0.920 & 0.684 & 4888 \\
\hline & $(66.49)^{*}$ & $(-32.59)^{*}$ & $(18.54)^{*}$ & $(-1.40)$ & $(6.03)^{*}$ & & \\
\hline
\end{tabular}

Notes: a) Omission of the zero pairs from the data set; ${ }^{*}$ : Statistically significant at the $99 \%$ level of confidence; ${ }^{* *}$ : Statistically significant at the $95 \%$ level of confidence; ${ }^{* * *}$ :Statistically significant at the $90 \%$ level of confidence; $(t$-statistics in parentheses); Dependent variable is $\log M_{i j}$.

For panel and all cross-section analyses, the $\mathrm{R}^{2}$ show values of more than 0.50 . In the first technique, only about $5 \%$ of the total data were neglected per year due to the zero pairs (the largest occurred in 2000). This tendency makes the Tobit technique seems less important to be executed. Table 7 illustrates that (see also Table 6 for comparison) only for 1992, the Tobit technique appears relevant, where the variable of AFTA establishment (DAFTA) is found to be statistically significant at $90 \%$ and has a positive impact in enhancing trade flows among its members. For the rest, the results of the first and the second techniques are almost similar.

Generally, our cross-section and panel analysis almost give a same conclusion in all periods. Four out of five independent variables were statistically significant at $99 \%$ (for $Y i . Y j$ and $D i j$ ); $95 \%$ (for some of $D A F T A$ ); $90 \%$ (for some of DAFTA), while Dborder was found to be statistically insignificant. The panel analysis looks a bit more robust in terms of explaining the DAFTA variable. Related to the effect of AFTA, our panel model find that the dummy variable for intra-regional trade in ASEAN (AFTA) contributes a significant positive effect to trade for most years (except in 1993 and 1997), suggesting that FTA can foster trade in ASEAN and bring a positive impact to their trade flows. 
According to the results, the role of FTA was less important in 1991-1998. However its role grew better in 1999 and 2000. Actually, this condition describes a bit about the criticism of the parties which believe that AFTA is still in its infancy in terms of its role in boosting trade flows among the members and enhancing economic development to the region (OECD, 1995). However, neglecting the period of crisis (1997), our results still corroborate the importance of FTA in fostering trade flows of a country in ASEAN region. From Tables 6 and 7, the variables of income, distance, and infrastructure show their significant expected signs while the variable of common border is found to be statistically insignificant. The variable of economic size (GDP) contributes a robust effect on ASEAN trade flows.

Table 7. Regression results with the second technique ${ }^{\text {b) }}$

\begin{tabular}{|c|c|c|c|c|c|c|}
\hline & $\log (\mathbf{Y} \mathbf{i} . \mathbf{Y j})$ & $\sqrt{ } \mathbf{D i j}$ & $\log ($ Infi.Infj) & Dborder & DAFTA & $\mathbf{N}$ \\
\hline \multicolumn{7}{|c|}{ Cross-Section Analysis } \\
\hline \multirow[t]{2}{*}{1990} & 0.912 & -0.038 & 0.356 & -0.440 & 1.107 & 428 \\
\hline & $(17.73)^{*}$ & $(-8.23)^{*}$ & $(7.96)^{*}$ & $(-0.46)$ & $(1.99)^{* *}$ & \\
\hline \multirow[t]{2}{*}{1991} & 0.877 & -0.036 & 0.373 & -0.369 & 1.127 & 431 \\
\hline & $(17.24)^{*}$ & $(-8.15)^{*}$ & $(8.32)^{*}$ & $(-0.39)$ & $(2.07)^{* *}$ & \\
\hline \multirow[t]{2}{*}{1992} & 0.864 & -0.041 & 0.371 & -0.288 & 0.821 & 429 \\
\hline & $(18.47)^{*}$ & $(-10.01)^{*}$ & $(8.86)^{*}$ & $(-0.33)$ & $(1.65)^{* * *}$ & \\
\hline \multirow[t]{2}{*}{1993} & 0.927 & -0.043 & 0.301 & -0.087 & 0.631 & 440 \\
\hline & $(19.87)^{*}$ & $(-10.57)^{*}$ & $(7.07)^{*}$ & $(-0.10)$ & $(1.26)$ & \\
\hline \multirow[t]{2}{*}{1994} & 0.929 & -0.038 & 0.301 & -0.287 & 0.894 & 441 \\
\hline & $(21.24)^{*}$ & $(-10.16)^{*}$ & $(7.39)^{*}$ & $(-0.35)$ & $(1.93)^{* * *}$ & \\
\hline \multirow[t]{2}{*}{1995} & 0.927 & -0.037 & 0.266 & -0.628 & 0.934 & 447 \\
\hline & $(22.74)^{*}$ & $(-10.53)^{*}$ & $(6.75)^{*}$ & $(-0.84)$ & $(2.17)^{* *}$ & \\
\hline \multirow[t]{2}{*}{1996} & 0.979 & -0.040 & 0.279 & -0.769 & 0.899 & 453 \\
\hline & $(21.37)^{*}$ & $(-10.22)^{*}$ & $(6.21)^{*}$ & $(-0.91)$ & $(1.87)^{* * *}$ & \\
\hline \multirow[t]{2}{*}{1997} & 1.123 & -0.039 & -0.002 & -0.360 & 0.807 & 450 \\
\hline & $(23.28)^{*}$ & $(-9.71)^{*}$ & $(-0.05)$ & $(-0.42)$ & (1.64) & \\
\hline \multirow[t]{2}{*}{1998} & 0.981 & -0.045 & 0.231 & 0.093 & 0.855 & 441 \\
\hline & $(19.74)^{*}$ & $(-10.96)^{*}$ & $(4.62)^{*}$ & $(0.11)$ & $(1.69)^{* * *}$ & \\
\hline \multirow[t]{2}{*}{1999} & 0.988 & -0.040 & 0.216 & 0.009 & 1.123 & 458 \\
\hline & $(21.26)^{*}$ & $(-10.21)^{*}$ & $(4.46)^{*}$ & $(0.01)$ & $(2.34)^{* *}$ & \\
\hline \multirow[t]{2}{*}{2000} & 0.983 & -0.046 & 0.282 & -0.371 & 1.041 & 464 \\
\hline & $(20.48)^{*}$ & $(-11.45)^{*}$ & $(5.51)^{*}$ & $(-0.42)$ & $(2.09)^{* *}$ & \\
\hline \multicolumn{7}{|c|}{ Panel Analysis } \\
\hline \multirow[t]{2}{*}{$1990-2000$} & 0.958 & -0.041 & 0.239 & -0.372 & 0.920 & 4888 \\
\hline & $(-66.54)^{*}$ & $(-32.61)^{*}$ & $(18.55)^{*}$ & $(-1.40)$ & $(6.03)^{*}$ & \\
\hline
\end{tabular}

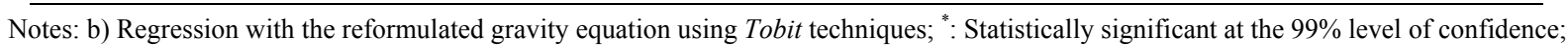
${ }^{* *}:$ Statistically significant at the $95 \%$ level of confidence; ${ }^{* * *}$ :Statistically significant at the $90 \%$ level of confidence; ( $t$-statistics in parentheses); Dependent variable is $\log M_{i j}$.

\section{Conclusion}

Using a cross-sectional and panel gravity model, this paper attempts to answer the questions, whether AFTA and infrastructure create gains to the trade flows of its member and whether other variables, such as economic size, distance, and common border influence the ASEAN trade flows. Our empirical findings were found to be generally consistent with the considered hypotheses. The results show that as a symbol of regionalism in ASEAN, 
AFTA was significant in bringing a positive impact to the trade flows among its member for most periods. The other factors, such as infrastructure, economic size (income), and distance also give statistically significant impact on the ASEAN countries' trade flows. Insignificant influence only appears for the effect of common border on ASEAN trade flows.

\section{References}

Anderson, J. E., \& Wincoop, V. E. (2003). Gravity with gravitas: A solution to the border effect puzzle. American Economic Review, 93, 170-192. http://dx.doi.org/10.1257/000282803321455214

Balassa, B. (1961). The theory of economic integration. Richard D. Irwin. Homewood, IL.

Batra, A. (2004). India's global trade potential: The gravity model approach. ICRIER Working Paper, 151.

Behr, T., \& Jokela, J. (2011). Regionalism \& global governance: The emerging agenda. Notre Europe Studies \& Research, 85.

Bergstrand, J. H. (1989). The generalized gravity equation, monopolistic competition, and the factor-proportions theory in international trade. Review of Economics and Statistics, 71, 143-153. http://dx.doi.org/10.2307/1928061

Bougheas, S., Demetriades, P. O., \& Morgenroth, E. L. W. (1999). Infrastructure, transport costs and trade. Journal of International Economics, 47, 169-189. http://dx.doi.org/10.1016/S0022-1996(98)00008-7

Brulhart, M., \& Kelly, M. J. (1999). Ireland's trading potential with Central and Eastern European countries: A gravity study. The Economic and Social Review, 30, 159-174.

De Melo, J., Panagariya, A., \& Rodrik, D. (1993). The new regionalism: A country perspective. In J. De Melo \& A. Panagariya (Eds.), New dimension in regional integration. Cambridge University Press. http://dx.doi.org/10.1017/CBO9780511628511.012

Egger, P. (2002). An econometric view of the estimation of gravity models and the calculation of trade potentials. World Economy, 25, 297-312. http://dx.doi.org/10.1111/1467-9701.00432

Greenaway, D., \& Milner, C. (2002). Regionalism and gravity. Scottich Journal of PoliticalEconomy, 49, 574 585. http://dx.doi.org/10.1111/1467-9485.00249

Matyas, L. (1997). Proper econometric specification of the gravity model. World Economy, 21, 363-368. http://dx.doi.org/10.1111/1467-9701.00074

McCallum, J. (1995). National borders matters: Canada-US regional trade patterns. American Economic Review, $85,615-623$.

Montenegro, C. E., \& Soloaga, I. (2006). NAFTA's trade effects: New evidence with a gravity model. Estudios de Economía, 33, 45-63.

OECD. (1995). Regional integration and the multilateral trading system synergy and divergence. Paris: OECD.

Plummer, M. G. (1996). The ASEAN free-trade area: Backwards or forwards. CAS Discussion Paper, 5.

Radelet, S. (1997). Regional integration and cooperation in sub-saharan africa: Are formal trade agreements the right strategy? The Discussion Paper of Harvard Institute for International Development, 592.

Rojas, G. E. A., Calfat, G. G., \& Flores, Jr. R. G. (2005). Trade and infrastructure: Evidence from the Andean community. EPGE Working Paper, 580.

Schiff, M., \& Winters, A. L. (1998). Dynamics and politics in regional integration arrangements: An introduction. World Bank Economic Review, 12, 177-195. http://dx.doi.org/10.1093/wber/12.2.177

Zarzoso, I. M., \& Lehmann, F. N. (2003). Augmented gravity model: An empirical application to Mercosur-European Union trade flows. Journal of Applied Economics, 6, 291-316.

\section{Copyrights}

Copyright for this article is retained by the author(s), with first publication rights granted to the journal.

This is an open-access article distributed under the terms and conditions of the Creative Commons Attribution license (http://creativecommons.org/licenses/by/3.0/). 